\title{
Irányzatok a brit vidékföldrajzban
}

\section{Approaches in British rural geography}

\author{
MIKLE GYÖRGY
}

MIKLE György: doktorandusz, Eötvös Loránd Tudományegyetem, Földrajz- és Földtudományi Intézet, Társadalom- és Gazdaságföldrajzi Tanszék; 1117 Budapest, Pázmány Péter sétány 1/c.; miklegyo@gmail.com; https://orcid.org/0000-0001-8490-6165

KULCSSZAVAK: társadalomföldrajzi irányzatok; vidékföldrajz; vidékkutatás; Egyesült Királyság

ABSZTRAKT: Az angolszász társadalomföldrajzban (human geography) több megközelítési mód, irányzat is elkülöníthető, ami szorosan összefügg a tudományág társadalomelméleti sokszínűségével. Jelen tanulmány ezeknek az irányzatoknak a brit vidékföldrajzi kutatásokra gyakorolt hatását elemzi. Az irányzatok egységes szempontrendszer szerinti jellemzésén (kialakulásuk kontextusa, a kutatások elméleti-filozófiai háttere, módszertanuk, az általuk vizsgált legfontosabb kérdéskörök, a rájuk adott kritikák) túl a brit vidékföldrajz közelmúltbeli állapotát is vizsgálja. Ez a Journal of Rural Studies 2000-es években megjelent lapszámainak elemzésén keresztül történik; a tanulmány a folyóirat elemzése során a brit intézményekben dolgozó szerzők által vagy közremúködésével készült munkákra fókuszál.

A tanulmány rámutat arra, hogy a brit vidékföldrajzi kutatások jellemzője a sokszínűség és a nyitottság. A sokszínűséget a különféle megközelítési módok, elméletikoncepcionális alapok sokfélesége jelenti. Az előzetesen elkülönített négy irányzat (pozitivista, politikai gazdaságtani, kulturális, relacionális) nem egyveretü, köztük számos átmenet, kapcsolat fedezhető fel. Az irányzatokon belül több áramlat is kialakult, valamint szembetűnő az elméleti alapok folyamatos újragondolása is, így az elméletben definiálható irányzatok a gyakorlatban nem válnak el egyértelműen. A nyitottság elsősorban a más tudományterületekkel történő élénk együttműködés formájában nyilvánul meg, a „vidékföldrajz” helyett gyakoribb a „vidékkutatás” megnevezés használata. Az irányzatok jelentősége leginkább az azonos témakörhöz köthető, de eltérő természetű kérdések feltevésében nyilvánul meg. A tanulmányban bemutatott közelítésmódok a magyar vidék térbeli-társadalmi folyamatainak alaposabb megértését, a problémák átgondoltabb és hatékonyabb kezelését is segíthetik, adaptálhatóságuk és relevanciájuk mérlegelését követően.

György MIKLE: PhD student, Department of Social and Economic Geography, Institute of Geography and Earth Sciences, Eötvös Loránd University; Pázmány Péter sétány 1/c., H-1117 Budapest, Hungary; miklegyo@gmail.com; https://orcid.org/0000-0001-8490-6165

KEYWORDS: approaches to human geography; rural geography; rural studies; United Kingdom

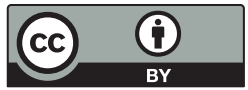


ABSTRACT: In the British academic context, the term 'human geography' refers to a wide range of approaches, which can be distinguished primarily by their philosophical-theoretical background and methods. This essay focuses on the approaches taken in British research on rural areas. It is based on some of the most significant publications in rural studies, and some contributions on the various approaches in general. It is based on an analysis of a wider range of studies in order to identify the main approach characteristics (specifically the context they emerged from; their philosophical-theoretical background; methods applied; key questions analysed; their critical reception). The empirical part of this essay seeks to investigate trends in British rural geography throughout the 2000s. For this purpose, publications from the Journal of Rural Studies were selected and analysed according to the approach taken.

The literature on rural geography generally defines four main approaches: positivistic; political-economic; cultural, and the so-called relational turn. Even if we can define and describe different approaches quite well theoretically, it is not easy to clearly categorise them in practice. A significant proportion of the publications selected from the Journal fused theories and philosophies of different approaches or made no reference to any philosophy in particular. The main finding of this analysis is that British rural geography can be described as a diverse subdiscipline, benefiting from a wide range of philosophies, theories and methods in order to understand the socio-spatial tendencies in rural areas. Revisiting previously elaborated theories in the light of the latest academic debates is also not uncommon. Another important characteristic of this sub-discipline is its openness, as there is a lively cooperation between geographers and researchers from other disciplines. The term 'rural studies' is widely used, acknowledging that the subject investigated is more important than disciplinary boundaries.

In conclusion, the characteristics of this sub-discipline as excercised in the UK are seen as strengths. Theoretical diversity and interdisciplinary openness ascribe greater heterogeneity to key questions, stimulate the emergence of new concepts, and provide the opportunity for understanding the processes in rural areas from more than one point of view. From a Hungarian perspective, these approaches offer a good basis for future research. Considering the diverse and complex problems of Hungarian rural areas, adopting some of these concepts may lead to more theoretically-conscious and better-underpinned analyses and can contribute significantly to understanding and handling the challenges ahead.

\section{Bevezetés}

Az elméleti pluralitással jellemezhető brit társadalomföldrajz (human geography) vidéki területekkel foglalkozó kutatói többféle társadalomelméleti alapra építenek vizsgálataik során. Kiemelten kutatott téma a vidéki térségek átalakulása, a tudományterület eszmetörténeti fejlődésére pedig jellemző, hogy a vizsgálatok szempontjai és kérdésfeltevésük módja is többször változott. Ez egyrészt a vidék fogalmának, illetve definíciójának sokrétűvé válásához vezetett, valamint a vidékföldrajz szemléletének folyamatos átalakulását hozta magával. Jelen tanulmány legfontosabb kérdése, hogy mi lehet az egyes tudományos közelítésmódok szerepe a vidéki folyamatok elemzésében: mely pontok mentén különböznek e közelítésmódok, és ez hogyan hat az így létrehozott tudományos tudásra. A cikk ezt szem előtt tartva az irányzatok kialakulásának és a vidékföldrajzban történő megjelenésének hátterét vizsgálja, valamint azt, hogy az ezredforduló után milyen e közelítésmódok helyzete. 
A magyar vidék társadalmi folyamatainak értékelését, értelmezését nagyban segítheti a cikkben elemzett irányzatok megismerése, a megfelelő szemléletmódok adaptálása. A tanulmánynak nem célja a brit kontextusnak vagy a tudományos tevékenységnek a magyarral való explicit összevetése, illetve az ezek közötti átmenetek, párhuzamok kifejtése. Ezzel együtt a vizsgálat relevanciája az itt bemutatott eredmények ilyen irányú továbbgondolásában rejlik. A vidékföldrajzi kutatások különféle megközelítési módjainak elemzésére kiváló alapot nyújt a brit geográfusok tevékenységének vizsgálata, hiszen a nyugati társadalomelméletek fejlődésében komoly szerepük van, azok alakításának aktív részesei (az angolszász hegemóniáról bővebben: Timár 2006; Timár et al. 2012; Valentine 2001). A tanulmány a fogalmi keretek és a módszertan tisztázása után négy irányzattal foglalkozik részletesen (pozitivista, politikai gazdaságtani, kulturális, relacionális), mindegyiket külön fejezetben tárgyalva.

\section{Elméleti és módszertani háttér}

A tanulmányban vizsgált megközelítési módok elemzése öt fö szempont alapján történik. Ezek kiválasztásában egyrészt Aitken és Valentine (2006) földrajzi irányzatok elemzésével foglalkozó tanulmányát vettem alapul, másrészt ezt kiegészítettem néhány olyan szemponttal, amelyek jelen cikk fó kérdéseinek megválaszolását jobban segíthetik. A tudományos tudás létrejöttében fontos szerepet tölt be és az irányzatok elemzésének első szempontját képezi a társadalmi-politikai helyzet, amelyet a tudománytanulmányokban az 1970-es évektől megjelenő szociálkonstruktivista vagy kontextualista szemlélet képviselői kezdtek vizsgálni (Gyimesi 2011). Érvelésük lényegi eleme a tudományos tudás társadalmi termékként való értelmezése, valamint annak hangsúlyozása, hogy a tudós nem független a társadalmi-hatalmi viszonyoktól, hiszen kérdésfeltevéseit, szemléletmódját jelentősen befolyásolja a társadalmi kontextus. Az irányzatok elkülönítésének második szempontja a hozzájuk köthető elméleti-filozófiai háttér vizsgálata, amelynek jelentőségét Aitken és Valentine (2006) is kiemelte. Rámutattak arra, hogy a filozófiai irányzatok szerepe a kutatások alapját képező előfeltevésekben, feltételezett összefüggésekben nyilvánul meg, ami jelentősen befolyásolja, hogy mely kérdések és milyen szempontból tekintendők relevánsnak. A tanulmány szempontrendszerének harmadik eleme az egyes irányzatok által kutatott kérdések vizsgálata. Fontos kiemelni, hogy az irányzatok szerint nem feltétlenül válnak el a fóbb vizsgált témák, hiszen gyakran ugyanannak a kérdéskörnek eltérő szempontú vizsgálata hívta életre a különféle megközelítési módokat. A földrajzi kutatások során fontos a vizsgálat alkalmazott módszereinek megválasztása, hiszen a különféle módszerek eltérő jellegű tudást eredményezhetnek (Aitken, Valentine 2006), ezért a jellemző kutatási módszerek áttekintése képezi az elemzés negyedik szempontját. Végül az irányzatok elemzésének ötödik 
szempontja a velük kapcsolatban megfogalmazott kritikák vizsgálata, amelyek ugyanakkor gyakran adták valamely másik irányzat alapvetését is.

Az irányzatok bemutatása és elemzése kronologikus sorrendet követ, így a földrajztudományban, majd a vidékföldrajzban való megjelenésük időpontja a legfontosabb rendező elv. A kutatás szövegelemzésen alapszik, amelynek fontos részét képezi a vidékföldrajz, vidékkutatás fejlődésével foglalkozó írások vizsgálata (Cloke 1997; Kovách 2012; Woods 2005, 2009a). A tanulmányomban elemzett irányzatok kiválasztásakor ezek a szintetizáló munkák jelentették az alapvető támpontot: a hivatkozott szerzők a pozitivista, a politikai gazdaságtani, illetve a kulturális közelítésmódokat tárgyalják részletesen. A negyedik irányzat, a relacionális fordulat földrajztudományban történő megjelenésére több szerző is utal (Anderson et al. 2012; Hess 2009; Jones 2009), és a közelítésmód a vidék kutatása kapcsán is egyértelmüen jelentkezik (Murdoch 2000). A vizsgált irányzatok vidékföldrajzi vonatkozásaival foglalkozó tanulmányok mellett a közelítésmódok általánosabb jellemzőit tárgyaló munkákra is támaszkodtam (Aitken, Valentine 2006; Gregory et al. 2009; Kitchin, Thrift 2009). Az irányzatok elemzése két lépcsőben történt. Először a fent hivatkozott, vidékkutatással foglalkozó munkákat a korábban bemutatott öt szempont szerint dolgoztam fel. Második lépésként néhány, ezekben hivatkozott írást elemeztem ugyanazon szempontok alapján. A második lépés során figyeltem arra, hogy földrajztudós szerzők munkáit válasszam ki, így a vizsgálatnak ez a része koncentrál szigorúan a vidék földrajzi kutatásának helyzetére, a többi feldolgozott irodalom esetén a brit tudományos kontextus sajátosságai miatt ez a különválasztás nem lett volna releváns (lásd később).

Az irányzatok általános jellemzése mellett azok közelmúltbeli helyzetének felmérése is a kutatás célja volt, amelynek alapját a Journal of Rural Studies 2000 és 2010 között megjelent lapszámainak vizsgálata képezte. A folyóirat kiválasztásánál szempont volt, hogy a Journal a brit vidékkutatás egyik legrangosabb folyóirata, az elemzésbe pedig a brit (az Egyesült Királyság területén található intézményben dolgozó) szerzők által írt publikációk kerültek be. Ez 154 tanulmány áttekintését jelentette, amelyeket egyrészt dolgozatom szempontrendszere alapján próbáltam irányzatokhoz sorolni, másrészt többször előfordult, hogy magában a cikkben történt utalás az alkalmazott közelítésmódra. Jelen dolgozatban ezek közül csak néhány olyan tanulmányra hivatkozom, amelyek szerzői is hivatkoznak valamely szemléletmódra, illetve amelyek segíthetnek az irányzatok ezredforduló utáni helyzetének illusztrálásában. Meg kell jegyeznem ugyanakkor, hogy a vizsgált publikációk nagyjából hatodát a fent jelzett szempontok alapján nem lehetett egyértelműen egyik irányzathoz sem sorolni, és a szerzőjük sem utalt erre. ${ }^{1}$

A vidék földrajzi kutatatásakor felmerülő alapvető kérdés, hogy miként definiáljuk magát a vidéket, illetve hogy mitől tekintünk egy kutatást földrajzinak. A brit tudományos életben ezekre a kérdésekre többen és többféle választ is adtak. A vidék definíciójával kapcsolatban elmondható, hogy az folyamatosan 
változott, aminek hátterében a vidék átalakulása (a reálfolyamatok), illetve az újabb irányzatok megjelenése (a vidékről való tudományos gondolkodás) állt (Kovách 2012; Woods 2005). Ehhez a folyamathoz részben kapcsolódik, hogy a vidékföldrajz meghatározása sem egyértelmű. Amint azt több szerző is kifejtette (Cloke 1985; Woods 2009b), a vidék kutatása megkívánja a különféle tudományterületek együttműködését, továbbá a földrajztudományon belüli párbeszéd is fontos. A más tudományterületekkel való együttműködést jól jelzi, hogy a kutatók körében általános a vidékkutatás (rural studies) kifejezés használata, a szerzők ritkábban hivatkoznak a vidékföldrajz (rural geography) tudományterületére. Tanulmányomban így elsősorban a vidéket kutató geográfusok munkásságát elemzem, azonban az itt bemutatott jellemzők nem kizárólag a földrajztudomány sajátjai. Ennek következtében a Journal of Rural Studies elemzett lapszámaiban a feldolgozott publikációk között is szerepelnek olyan munkák, amelyek nem, vagy nem kizárólag földrajzi profilú intézményekben dolgozó kutatók eredményeit mutatják be. Az elemzett folyóirattal kapcsolatban fontos kiemelni, hogy kifejezett célja a vidék kutatása során a különböző tudományterületek közötti együttműködés ösztönzése (Cloke 1985). Az interdiszciplináris környezet így a földrajztudományi háttérrel rendelkező kutatók által végzett kutatásokra is hat, a többi tudományterület jellemzői a vidékföldrajzosok munkáiban is visszaköszönnek.

\section{Pozitivista vidékföldrajzok}

A földrajztudományban a második világháborút követően újfajta szemlélet kezdett kibontakozni. Amíg a korábbi munkákra az egyediség vizsgálata volt jellemző, az új közelítésmód általános törvényszerüségek kutatását tűzte ki célul. Ez a felfogás az 1950-es években terjedt el a „kvantitatív forradalom” időszakában - a földrajz mellett más társadalomtudományokban is -, és az évtized végére teljesedett ki. Az irányzat kibontakozására a hidegháború politikai kontextusában került sor. Az állam fejlesztéspolitikai, társadalomszervezési szerepvállalásai is erős hatást gyakoroltak a tudomány helyére, és határozott igényeket támasztottak a tudományos tudás jellege és tartalma iránt. A kutatók legfontosabb motivációja ekkor a tudomány presztízsének megőrzése, a döntéshozatal hatékony segítése volt, így az alkalmazott kutatások kerültek előtérbe. Fontos kutatási kérdéssé vált például a fejlesztéspolitikához köthető településosztályozás, a vidéki területek kvantitatív módszerekkel történő lehatárolása (ennek friss példái Bibby, Brindley 2013; Shepherd, Bibby 2001).

Jelentős volt továbbá a mezőgazdasági termelés alakulásának elemzése. Bowler (1985) például a mezőgazdaság iparosításának hatásait vizsgálta, kevés figyelmet fordított ugyanakkor a folyamatokkal összefüggő társadalmi jelenségekre. A tanulmány végén található irodalomjegyzék is sokat elárul annak 
szemléletéről, hiszen a fejlesztéspolitikai jellegű dokumentumok, a mezőgazdasági termelés támogatási rendszerével foglalkozó írások vannak többségben, valamint egy - a von Thünen által kialakított - térbeli szerveződési modellt vizsgáló tanulmány is megjelenik. A pozitivista munkák jellemzője az univerzális modellek, kvantitatív módszerek használata, hiszen a szemléletmód dominánssá válásakor a kutatók úgy tekintettek a tudományra, mint amely semleges tudást képes eloállítani, tagadták bármiféle filozófiai háttér szükségességét (Kitchin 2006). Az elméleti hátteret képező modellek általában a közgazdaságtanból, később egyre nagyobb arányban a szociálpszichológiából származtak (Woods 2005). A vidék földrajzi kutatása számára a pozitivista szemléletmód elterjedése kezdetben komolyabb visszaesést jelentett, hiszen a folyamatosan háttérbe szoruló regionális földrajzi irányzat javarészt vidéki térségeket vizsgált (Cloke 1997).

A Journal of Rural Studies elemzett lapszámaiban a pozitivista szemléletmód jellegzetességeiből adódóan a szerzők nem hivatkoznak erre az irányzatra. Leginkább a módszertan szerepének hangsúlyozása, annak részletezése jellemző, ugyanakkor előfordulnak bizonyos elméleti hátteret megnevező pozitivista tanulmányok is. Walford (2007) például a vidéki térségekben megfigyelhető migrációs folyamatok hátterét geodemográfiai módszerek segítségével elemezte, munkáját ugyanakkor igyekezett elméleti kontextusba helyezni, így a publikációban a más irányzatokra (strukturalista és kulturális megfontolások) történő reflektálás is megjelent. Alsos és Carter (2006) farmokhoz kötődő termelési stratégiákat elemzett, amelynek során az úgynevezett erőforrásalapú közelítésmódot, illetve a stratégiai menedzsmentelméletet nevezték meg elméleti alapként. Az elemzett lapszámokban megjelent pozitivista szemléletű munkák nagy része fejlesztéspolitikával kapcsolatos témát dolgozott fel. Gyakran volt megfigyelhető a korábbi fejlesztéspolitikák kritikája is, azonban ezek alapfeltevését, végső célját nem kérdőjelezték meg: a szerzők a korábbi fejlesztéspolitikai célok fenntartását (például a farmgazdaságok termelékenységének növelését), azok jobb megvalósulását tekintették a legfőbb célnak. Ennek érdekében elsősorban a politikák és az azokat megalapozó kutatások módszertani reformját szorgalmazták. Winter (2000) például szociálpszichológiai, viselkedéstani modellek alkalmazására tett javaslatot a fejlesztéspolitikák meghatározásakor, amelyek segítségével érthetőbbé válnának a farmerek válaszreakciói bizonyos fejlesztéspolitikai lépésekre (a viselkedéstani modellek szerepét például Beedell, Rehman 2000, illetve Walford 2003 is kiemelte). A mezőgazdasági termelés elemzése mellett a fogyasztás vizsgálata is megjelent az elemzett publikációkban.

Kevesebb tanulmány foglalkozott társadalmi kérdésekkel, ezek jellemzője volt, hogy elsősorban modelleken alapultak és nagy mintát vizsgáló felmérésekre, adatbázisokra épültek. A többségében kvantitatív munkák nagy hangsúlyt fektettek a számítások módszertani részleteire. Ennek szerepe a többi irányzat esetén jellemző társadalomelméleti, térelméleti háttérhez hasonlítható, mivel a szerzők ezt tekintették a kutatás eredményeit alapvetően befolyásoló tényező- 
nek. A kvantitatív eszköztár mellett több esetben is megfigyelhető volt kvalitatív kutatási módszerek alkalmazása, azonban az eredmények értékelése főként kvantitatív formában történt (Phillipson et al. 2004). A pozitivistának minősíthető munkák aránya magasnak mondható a vizsgált időszakban, ami fóként az általuk vizsgált kérdések természetéből adódik. A kvantitatív módszertan és az ehhez kapcsolódó modellezés népszerüsége az alkalmazhatóság, valamint a fejlesztéspolitikák logikájához való illeszthetőség következménye.

\section{A politikai gazdaságtan és a vidékföldrajz}

A pozitivista tudományszemlélet, illetve a tudományos tevékenység kritikájaként fogalmazódott meg, hogy a kutatók a politikai hatalom céljainak szolgáltatják ki a tudományt, miközben magukra a tudás semleges közvetítőiként tekintenek. A szemléletváltásban fontos szerepe volt az 1960-as évektől az Egyesült Államokban és Nyugat-Európában megfigyelhető hidegháború-ellenes hangulatnak, polgárjogi mozgalmaknak. Ennek hatására a társadalomtudományokban a fennálló társadalmi rendet, a tudástermelés folyamatát megkérdőjelező kritikai szemléletmódok jelentek meg, amelyek a földrajztudományban is jelentkeztek. A vidékkutatásokban is megfigyelhető volt a politikai gazdaságtani perspektíva térnyerése, azonban csak az 1980-as években (Kovách 2012; Woods 2005, 2009a), ami a földrajztudomány más területeihez képest egy évtizedes késést jelentett. Ez a szemléletmód a gazdasági folyamatok és a társadalmi szerveződés módjai közötti összefüggéseket vizsgálja, így például a társadalmi viszonyokat a domináns termelési mód, a kapitalizmus jellegzetességeiből vezeti le. A politikai gazdaságtan több áramlata is megkülönböztethető, amelyek főként elméleti, filozófiai hátterükben válnak el egymástól. Az irányzaton belül kezdetben a strukturalista marxista szemléletmód dominált, később azonban a posztmodern, illetve posztstrukturalista elméletek terjedése a politikai gazdaságtani kutatásokra is hatott (Peet, Thrift 1989). ${ }^{2}$

A pozitivista munkákban meghatározó téma volt a mezőgazdasági termelés vizsgálata, a politikai gazdaságtani szemlélet hatására a kérdéskör elemzésének módja jelentősen átalakult. Marsden és szerzőtársai (1986) például a kapitalizmus jellegzetességeinek a termelésre gyakorolt hatásait és társadalmi következményeit helyezték elötérbe. Fontos szemponttá vált az agrártársadalom osztályszerkezetének alakulása, a családi farmok átalakulása a kapitalizmusban, illetve az állam és a mezőgazdasági termelés viszonyának kutatása. Az ellenurbanizáció az Egyesült Királyság vidéki területeinek egyik meghatározó társadalmi folyamata volt az 1980-as években, amelynek mechanizmusát és következményeit a politikai gazdaságtani szemléletmód segítségével igyekeztek megérteni a kutatók. Cloke és Thrift (1987) tanulmányukban a társadalmi osztályok helyzetének alakulását vizsgálták, és az osztályok közötti konfliktusokon 
túl az osztályokon belüli ellentétek kiéleződésére is rámutattak. Az ellenurbanizáció során előtérbe kerülő társadalmi osztály az úgynevezett szolgáltató osztály (service class) volt, amely a középosztályhoz tartozó, menedzseri vagy adminisztratív jellegü munkát végző, magas szintű képzettséggel rendelkező munkaerőt foglalt magába (Woods 2005). A gyáripari tevékenységek vidéki térségekbe történő áthelyeződését Thrift (1987) a szolgáltató osztály migrációs mintázataival hozta összefüggésbe. Tanulmányában az átmenetet jelző statisztikákat a szolgáltató osztály politikai és gazdasági pozíciója és igényei alapján értelmezte. Ennek során arra is rámutatott, hogy miként befolyásolja a vizsgált osztály migrációja a többi osztályt és a gazdasági tevékenységeket.

A politikai gazdaságtani szemlélethez kapcsolódó tudományos viták közül az úgynevezett localities debate (vita a lokalitásról) a vidéki térségek viszonylatában is felmerült. Ennek lényege az volt, hogy a vidéket meg lehet-e különböztetni más térségtípusoktól strukturális jellemzői alapján (Halfacree 1993). Barlow (1986) tanulmányában a földtulajdonviszonyok osztálystruktúrára gyakorolt hatását, ennek változásait elemezte, összefüggésben a mezőgazdaság szerepének háttérbe szorulásával. Munkájában rámutatott arra, hogy a földtulajdon továbbra is fontos alakítója az osztályviszonyoknak, azonban szerepe némileg átalakult, így árnyalni kell a vidéket lokalitásként értelmező munkák következtetéseit. Amint ebből a tanulmányból is kitűnik, a politikai gazdaságtan strukturalista szemléletmódja megkérdőjelezte a vidékiség magyarázó erejét, vizsgálatának jelentőségét. A tágabb struktúrák vizsgálata egyre kisebb teret adott a vidéki folyamatok önmagukban történő elemzésének, ami kritikaként merült fel e szemléletmóddal szemben (Woods 2009a). Egy másik kritika a feminista áramlat felől érte a politikai gazdaságtant. Ennek lényege az volt, hogy az osztálykülönbségek vizsgálata helyett a társadalmi nem szerepére kell nagyobb hangsúlyt fektetni, így például a strukturalista politikai gazdaságtan által alkalmazott osztályhierarchia helyére a patriarchális társadalom vizsgálata került a feminista munkákban. A feminista szemléletmód ugyanakkor a vidék kutatásában később - csak az 1980-as évektől - bontakozott ki, és érdeklődési területe is korlátozottabb volt, mint a városokkal foglalkozó munkákban (Little 1986; Little, Panelli 2003).

A Journal of Rural Studies elemzett lapszámaiban a politikai gazdaságtani szemléletmódra hivatkozó tanulmányok esetén megfigyelhető a közelítésmódok újraértékelése, a megújításukra való törekvés. Murray (2001) tanulmányában a gyarmatosítások időszakát és a neoliberális gazdasági modell globális terjeszkedését állította párhuzamba, és a csendes-óceáni szigetvilág államainak példáján keresztül értékelte ezeknek a folyamatoknak a hatását. A nemzetgazdaságok függőségi viszonyainak következményeit több szempontból vizsgálta, amelyek közül fontos volt a helyi agrártársadalom differenciálódása. A vonatkozó szakirodalmon kívül elsősorban társadalom- és gazdaságstatisztikákra támaszkodott, a különböző szinteken tapasztalható változások egymásra hatását hangsúlyozva. 
Jól példázza a politikai gazdaságtan elméleti átalakulását Robson (2004) munkája, aki a gyermekek gazdasági termelésben betöltött szerepét elemezte egy észak-nigériai esettanulmányban. Tanulmányában a feminista politikai gazdaságtani szemléletmódot nevezte meg kutatása alapjaként, ugyanakkor többször hivatkozott olyan munkákra, elméletekre is, amelyek a kulturális fordulattal kaptak nagyobb hangsúlyt a vidék kutatásában. Az általa végzett empirikus kutatás során interjús adatfelvételt alkalmazott, amely módszertan szintén főleg a feminista, illetve a kulturális szemléletmódokkal nyert teret. Összességében elmondható, hogy a politikai gazdaságtani szemlélet napjainkban kevésbé népszerü, valamint az ezt alkalmazó, erre hivatkozó tanulmányok általában más elméleti forrásokra is támaszkodnak, és a szemléletmód megújítására törekednek.

\section{A kulturális fordulat}

Az 1980-as évek végén az angolszász társadalomtudományokban lezajlott kulturális fordulat (cultural turn) a politikai gazdaságtan korábbi, materiálisabb szemléletét is módosította, alapvetően új kérdések kerültek a vizsgálatok fókuszába. A szemléletváltáshoz kapcsolódóan a földrajztudomány nyitottabbá vált más társadalomtudományok felé, ami az elméletekben és a módszertanban (a kvalitatív módszertan alkalmazása került előtérbe) is tetten érhető volt, és egyben a földrajzi kutatások sokszínűbbé válását jelentette (Barnett 2009).

A kulturális szemlélet - Cloke (1997) szerint - a vidékföldrajzi kutatások megélénküléséhez vezetett, amit a Journal of Rural Studies folyóirathoz publikálásra benyújtott tanulmányok számának növekedésén, valamint a vidékkel foglalkozó földrajzi, illetve más társadalomtudományi hátterü könyvek számának gyarapodásán keresztül tapasztalt. A kulturális fordulat mögött posztmodern és posztstrukturalista elméleti, filozófiai háttér állt. Ezek közös jellemzője, hogy olyan, korábban a tudástermelés szereplői által elfogadott axiómákat kérdőjeleztek meg, mint például a fejlődés, a fejlesztés, az egyenlősítő, emancipatív törekvések, valamint az ezekkel kapcsolatos fogalmak hátterét és azok létrehozását kezdték vizsgálni. A fordulattal a kutatók figyelme a reprezentáció, a diskurzus szerepére és ezek elemzésére irányult, így a "mit” helyett a „hogyan” vált a legfontosabb kérdéssé, csökkent ugyanakkor a materiális természetü vizsgálatok jelentősége (Clarke 2006; Harrison 2006).

Az új szemléletmód hatására például a vidék reprezentációja, a vidékkel kapcsolatos elbeszélésmódok, élmények vizsgálata vált jellemzővé, illetve a vidéket társadalmi termékként kezdték kezelni (Kovách 2012; Woods 2005, 2009a, 2010). ${ }^{3}$ A legfontosabb kérdéssé az vált, hogy az egyes szereplők miként nyilvánítják ki vidékiségüket, aminek hatására a társadalmi különbségek új di- 
menziói is előtérbe kerültek - megjelent a vidéki „mások” vizsgálata (Woods 2009a). A társadalmi nem szerepének értékelése is új szempontokkal gyarapodott, így a materiális formában megnyilvánuló egyenlőtlenségek helyett azok diskurzív újratermelése vált fontosabb kérdéssé (Little, Panelli 2003). Megjelent például a vidéki térhez köthető szimbolikus gyakorlatok elemzése (Little, Leyshon 2003), a családi farmokon megfigyelhető, munkamegosztással kapcsolatos beszédmódok értékelése (Whatmore 1991). A vidékiséghez kötheto” diskurzusokat elemző munkák között megfigyelhetők a szakértői, kutatói tevékenységet vizsgáló írások (Edwards 1998), vagy a helyi elit beszédmódját, önlegitimációs stratégiáit elemző tanulmányok (Woods 1997). A diskurzusokon túl később a velük összefüggő, hozzájuk kapcsolódó gyakorlatok (performances) vizsgálata is jellemzővé vált, például Holloway és Kneafsey (2000) tanulmánya a termelői piacokon vásárlók motivációival foglalkozott. A gyakorlatok vizsgálata elsősorban a szemléletmódot ért azon kritikák hatására jelent meg, amelyek a materiális kérdések kutatásának háttérbe szorulására világítottak rá (Woods 2010). A kulturális perspektíva új szempontokkal gyarapította a mezőgazdasági termelés kutatását is, amelyről Morris és Evans (2004) írt részletesen. Megjelentek a termelés ábrázolásának módjait elemző, a médiában vagy a fejlesztéspolitikai dokumentumokban megfigyelhető és a mezőgazdasági termeléshez kapcsolódó diskurzusokat vizsgáló munkák. Elemezni kezdték például a minőségi élelmiszer fogalmának társadalmi konstrukcióját. A természet és a társadalom kapcsolatának kutatása is új szempontokkal gyarapodott, amelynek egyik koncepcionális pillére a cselekvő-hálózat elmélet (például Owain 2003). (Az elmélet hatására például az állatállományra nem csupán a termelés elszenvedőjeként, hanem annak alakítójaként kezdtek tekinteni.)

A kulturális fordulattal terjedő szemléletmód a Journal lapszámaiban is megjelent. Phillips, Fish és Agg (2001) például a média szerepét értékelték a vidékkép létrehozásában, amellett érveltek, hogy a vidéki terek ábrázolásának módja a középosztály igényeit tükrözi. Ez a szemléletmód gyakran jelenik meg a vidéki térségekben zajló településfejlesztés során is, amely az oda nem illőnek tartott elemek mellőzéséhez, így bizonyos társadalmi csoportok marginalizációjához járul hozzá. A vidékhez köthető beszédmódok társadalmi szerepét a kulturális szemléletủ munkák zöme hasonló módon - egyes társadalmi csoportokat ért negatív hatások szempontjából - mutatta be (Jones 2002; Matthews et al. 2000). Az elemzett publikációk nagy részében a vidékkel kapcsolatos diskurzusok a különböző marginalizált társadalmi csoportok helyzetével foglalkoznak, módszertanilag ezek a munkák általában interjúkon, médiatartalmak elemzésén vagy szövegelemzésen alapulnak. A vizsgált lapszámokból világosan kirajzolódik, hogy a kulturális perspektíva szerepe és a rá hivatkozó publikációk aránya a 2000-es években kiemelkedő volt. 


\section{A relacionális fordulat hatása a vidékföldrajzra}

A kulturális fordulat során fontos szerepet játszó posztstrukturalista, illetve szociálkonstruktivista nézőpontok a gazdasági folyamatok vizsgálatában is jellemzővé váltak. Az 1980-as évek végére erőteljesen átalakuló gazdasági környezet és ezzel együtt a gazdasági szereplők kapcsolatainak minőségi változása új koncepcionális keret kialakulását eredményezte (Boggs, Rantisi 2003). Így például a nemzetállami helyett más földrajzi léptékek szerepe értékelődött fel, az állam helyett a piac, a termelés helyett a fogyasztás szerepe vált hangsúlyossá. Az 1990-es években a társadalomtudományokban, majd a 2000-es évektől a földrajztudományban jelentkező szemléletmódot a kutatók relacionális fordulat néven foglalták össze (Anderson et al. 2012; Hess 2009; Jones 2009). Az új közelítésmód lényegi eleme volt, hogy a cselekvők közötti interakciók vizsgálatára, valamint az ezek keretét képező kontextus (intézményi, kulturális) elemzésére helyezték a hangsúlyt (Boggs, Rantisi 2003).

A vidéki folyamatok kutatásában is jelentkeztek a szemléletmódhoz köthető elméletek. A beágyazottság (Hess 2009) képezte Winter (2003) munkájának koncepcionális keretét, angliai és walesi példákban mutatva be a sajátos vásárlói motivációk gazdasági következményeit, így a helyi termelőket előnyben részesítő helyi lakosság kulturálisan, társadalmilag beágyazott preferenciáit. Az állam és intézményeinek szabályozó szerepét, valamint az egyéni érdekek, preferenciák következményeit egyaránt szem előtt tartó kormányozhatóság (Hakli 2009) koncepciója is a szemléletmód elterjedését példázza. A helyi szereplők egymáshoz való viszonyát például a fentebb említett cselekvő-hálózat elmélet vagy a társadalmi tőke perspektívájából vizsgáló tanulmányok is a relacionális fordulat hatását tükrözik. A cselekvő-hálózat elméletet a helyi közösségek müködésének, a vidéki települések politikai konfliktusainak komplex elemzésére is hasznosnak találták a kutatók (Woods 1998). Az egyének kapcsolatainak rendszerét és a benne rejlő potenciált jellemző társadalmi tőke vizsgálata is megjelent a vidékföldrajzi kutatásokban. Ennek egy példája az a kutatás, amely a vállalkozások sikeressége és a vállalkozók kapcsolati hálója közötti összefüggést elemezte vidéki terekben (Moyes et al. 2015). Az úgynevezett assemblage-gondolatkör (erről bővebben lásd Anderson et al. 2012; Bingham 2009) alkalmazására is egyre több példa található a vidékföldrajzi kutatásokban. Az elmélet olyan vizsgálatok kapcsán került előtérbe, mint például Mason és Hope (2014) természetvédelmi témájú írása, amely a denevérek élőhelyeinek felméréséhez köthető gyakorlatokat vizsgálta. Ennek során arra mutattak rá a szerzők, hogy az ember (a felmérést végző kutatók), a technológia (a felméréshez használt ultrahangos detektorok), valamint az állatok (a felmérni kívánt denevérpopuláció) együttes jelenléte és együttműködése miként hoz létre új entitást. A bemutatott szemléletmódhoz kapcsolódóan a kvalitatív kutatási módszerek alkalmazása terjedt el (interjúzás, diskurzuselemzés vagy résztvevő-megfigyelés), és az elemzett tanulmányokra is ez volt a jellemző. A szemléletmódot elsősorban 
strukturalista érvek mentén támadták, mivel gyakran volt megfigyelhető az aktorok szerepének, szabadságának túlzott hangsúlyozása (Boggs, Rantisi 2003).

A Journal elemzett lapszámaiban több szerző is hivatkozott az említett koncepciókra, például a kormányozhatóságra (Enticott 2001; MacKinnon 2002; Thompson 2005). A vidéki térségek gazdasági folyamatait kívánta koncepcionális keretbe foglalni Murdoch (2000), amely során több elmélet ötvözését javasolta. Álláspontja szerint a mezőgazdasági és az ahhoz kötődő tevékenységek vizsgálata a makrostruktúrákban gondolkodó (elsősorban a politikai gazdaságtani munkákban elterjedt) áruláncok és a cselekvő-hálózat elmélet együttes használatát kívánná. Kiemelte ugyanakkor az innovációs hálózatkutatás szerepét, amelynek segítségével az intenzív és alulról építkező, helyi szereplőkre támaszkodó gazdaság működése érthető meg. A szerző így a relacionális fordulat által hangsúlyozott átmenetiségre, az entitások interakcióinak vizsgálatára hívta fel a figyelmet, amellett, hogy a politikai gazdaságtani szemléletet is beépítette koncepcionális keretébe. Az elemzett lapszámokban megjelenő, a relacionális fordulat szemléletét tükröző tanulmányok jellemzője, hogy tudatosan használják a közelítésmódot, hiszen döntő többségük hivatkozott a fent bemutatott koncepciókra. Ezzel együtt az irányzathoz tartozó tanulmányok aránya csekélynek mondható a vizsgált időszakban.

\section{Összegzés}

A tanulmány a vidék földrajzi kutatásának megközelítési módjait elemezte, amelyen keresztül rámutatott arra, hogy a brit vidékföldrajz egyik jellemzője a sokszínűség. Ez egyrészt az elméleti-koncepcionális alapok sokféleségében, másrészt a vizsgálat módszereinek diverzitásában ölt testet. Ugyan az egyes irányzatok nagy részének megjelenése és adaptálása eredetileg egy adott történelmi kontextushoz kötődött és bizonyos kérdések mentén került felhasználásra a vidék földrajzi kutatásában (1. táblázat), az elméleti-koncepcionális alapok megtartásával a jelenlegi folyamatok, napjainkban releváns kérdések kutatására, értelmezésére is lehetőséget nyújtanak. Ennek jegyében megfigyelhető az egyes elméletek folyamatos újragondolása, a sokféle kutatott kérdéshez való idomítása is. Ez a folyamat az egyes irányzatokat belülről alakítja át, így például a politikai gazdaságtan kezdeti strukturalista marxista gondolatvilága mellett megjelentek más (például feminista, posztstrukturalista) jegyeket hordozó közelítésmódok is. Az elemzés megerősíti, hogy az egyes perspektívák közötti átmenetek és kapcsolatok leginkább a kritikák mentén érthetők meg. A szemléletmódok korlátaira rámutató tudományos viták kimenetele legtöbbször valamilyen új gondolatkör kibontakozása volt, ugyanakkor általában a kritizált irányzat is módosult ezek hatására. Az irányzatok létrejöttének jelentőségét talán legjobban a vizsgált kérdések átalakulása mentén lehet megragadni, ebből 
jól látható, hogy egy-egy témakör vizsgálata kapcsán miként jelentkeznek újabb szempontok. Kirajzolódik például, hogy a mezőgazdasággal foglalkozó munkák egy része a termelés volumenére, a támogatási rendszer fejlesztésére koncentrál (pozitivista irányzat), más részük az agrártársadalom osztályszerkezetét, az állam és a mezőgazdaság kapcsolatának kritikai elemzését tartja szem előtt (politikai gazdaságtan), valamint megjelennek a termelés médiareprezentációját, a hozzá kapcsolódó diskurzusokat bemutató tanulmányok (kulturális fordulat), illetve a helyi gazdaság szereplőinek kapcsolatrendszerét vizsgáló elemzések (relacionális fordulat).

1. táblázat: A vidékföldrajz irányzatainak jellemzői The main characteristics of the approaches analysed

\begin{tabular}{|c|c|c|c|c|c|}
\hline Irányzat & $\begin{array}{c}\text { A megjelenés } \\
\text { kontextusa }\end{array}$ & Filozófia, elmélet & Vizsgált kérdések & Módszerek & Kritikák \\
\hline Pozitivista & $\begin{array}{l}\text { Hidegháború; a } \\
\text { tudomány a ha- } \\
\text { talom szolgála- } \\
\text { tában }\end{array}$ & $\begin{array}{l}\text { Pozitivizmus; } \\
\text { „elméletnélkü- } \\
\text { liség” }\end{array}$ & $\begin{array}{l}\text { Mezőgazdasági } \\
\text { termelés, terü- } \\
\text { lethasználat, } \\
\text { területi terve- } \\
\text { zés }\end{array}$ & $\begin{array}{l}\text { Adatelemzés, } \\
\text { kvantitatív } \\
\text { módszerek, } \\
\text { modellek }\end{array}$ & $\begin{array}{l}\text { Politikai célok } \\
\text { szolgálata, a } \\
\text { kutató nem } \\
\text { semleges }\end{array}$ \\
\hline $\begin{array}{l}\text { Politikai gazda- } \\
\text { ságtani }\end{array}$ & $\begin{array}{l}\text { Átalakuló vi- } \\
\text { dék, (hideg)há- } \\
\text { ború-ellenes } \\
\text { hangulat }\end{array}$ & $\begin{array}{l}\text { Marxizmus, } \\
\text { strukturaliz- } \\
\text { mus }\end{array}$ & $\begin{array}{l}\text { Társadalmi osz- } \\
\text { tálystruktúra, a } \\
\text { vidék átalaku- } \\
\text { lása, a kapita- } \\
\text { lizmus hatása a } \\
\text { vidéki folyama- } \\
\text { tokra }\end{array}$ & $\begin{array}{l}\text { Adatelemzés, } \\
\text { makrofolyama- } \\
\text { tok statisztikái- } \\
\text { nak kritikai ér- } \\
\text { tékelése }\end{array}$ & $\begin{array}{l}\text { A vidékiség sze- } \\
\text { repének elha- } \\
\text { nyagolása, az } \\
\text { osztálystruk- } \\
\text { túra szerepé- } \\
\text { nek túlértéke- } \\
\text { lése, poszt- } \\
\text { strukturalista } \\
\text { érvek }\end{array}$ \\
\hline $\begin{array}{l}\text { Kulturális for- } \\
\text { dulat }\end{array}$ & $\begin{array}{l}\text { A kétpólusú vi- } \\
\text { lágrend meg- } \\
\text { szűnése, } \\
\text { „posztmodern } \\
\text { kor” }\end{array}$ & $\begin{array}{l}\text { Posztmodern, } \\
\text { posztstruktura- } \\
\text { lista szemlélet- } \\
\text { módok }\end{array}$ & $\begin{array}{l}\text { A vidék repre- } \\
\text { zentációja, dis- } \\
\text { kurzív konstru- } \\
\text { álása, szimboli- } \\
\text { kus gyakorla- } \\
\text { tok, marginali- } \\
\text { zált, „rejtett” } \\
\text { társadalmi cso- } \\
\text { portok }\end{array}$ & $\begin{array}{l}\text { Szövegelemzés, } \\
\text { médiatartal- } \\
\text { mak, műalkotá- } \\
\text { sok elemzése, } \\
\text { interjú }\end{array}$ & $\begin{array}{l}\text { Elszakadás a } \\
\text { materialitástól }\end{array}$ \\
\hline $\begin{array}{l}\text { Relacionális } \\
\text { fordulat }\end{array}$ & $\begin{array}{l}\text { A gazdasági fo- } \\
\text { lyamatok mi- } \\
\text { nőségi válto- } \\
\text { zása }\end{array}$ & $\begin{array}{l}\text { Posztstruktura- } \\
\text { lista szemlélet- } \\
\text { módok }\end{array}$ & $\begin{array}{l}\text { Helyi gazdaság- } \\
\text { fejlesztés, hib- } \\
\text { rid entitások, a } \\
\text { társadalom és a } \\
\text { természet kap- } \\
\text { csolata, globali- } \\
\text { záció }\end{array}$ & $\begin{array}{l}\text { Interjú, részt- } \\
\text { vevő-megfigye- } \\
\text { lés }\end{array}$ & $\begin{array}{l}\text { Az aktorok sze- } \\
\text { repének túlzott } \\
\text { hangsúlyozása }\end{array}$ \\
\hline
\end{tabular}


Tanulság, hogy a szakirodalmak által és eszmetörténeti alapon lehatárolt irányzatok az esetek jelentős részében nem azonosíthatók egyértelműen. Ennek egyik oka, hogy sokszor maguk a kutatók sem tudatosan használnak bizonyos megközelítési módokat, vagy éppen az elméletek szélesebb körére szeretnék építeni vizsgálatukat, aminek hatására „hibrid” megközelítési módok jönnek létre. Brit kontextusban a vidékföldrajz másik jellegzetessége a nyitottság, amely a más tudományágakkal való intenzív együttműködésben ölt testet. A vizsgált folyóirat, a Journal of Rural Studies alapításától fogva támogatja ezt a nyitottságot, így a folyóirat címe is jelzi, hogy a hangsúly a vizsgált entitáson, jelen esetben a vidéken van, nem pedig az egyes tudományterületeken. A vidékkutatás fogalmának használata elterjedt a szakirodalomban, a kutatók gyakran nem is törekednek saját tudományterületük megnevezésére vagy kiemelésére. Az elemzés tanulsága, hogy a vidék kutatásának nyitottsága és sokszínűsége a társadalmi folyamatok alaposabb, mélyebb megértését teszi lehetővé. A magyar vidéki térségekben megfigyelhető tendenciák vizsgálata, a fejlesztések alapját jelentő kutatások során érdemes a különféle megközelítési módok alkalmazását mérlegelni, hiszen a megfelelő elméleti-koncepcionális alapok és módszertan tudatos alkalmazásával és a hazai viszonyokhoz való idomításával jobban megérthetjük a vidék társadalmi folyamatait. A hazai vidéki térségek megoldatlan problémáinak sokfélesége pedig nem csupán lehetővé teszi, de meg is kívánja az átgondolt, elméletileg is megalapozott kutatások művelését.

\section{Jegyzetek}

$1 \quad$ Ezeknek a tanulmányoknak egy része olyan elméletre hivatkozott, amely az általam vizsgált irányzatok egyikére sem jellemző. Néhány tanulmány ugyanakkor több, különböző irányzatra jellemző koncepciót vegyített. Olyan munkák is voltak, amelyek nem hivatkoztak elméleti alapra, azonban az általuk vizsgált kérdés megközelítésének módja, valamint a módszertan alapján nem mondhatók pozitivistának.

2 Timár és Velkey (2016) rámutattak arra, hogy a magyarországi vidéki folyamatok vizsgálatával gyakran jár együtt egyfajta politikai gazdaságtani szemlélet alkalmazása, amely elsősorban az állam vidékfejlesztő szerepére fókuszáló írásokban ölt testet.

3 A magyar társadalomföldrajzban ez a szemlélet jelent meg például G. Fekete Éva és Lipták Katalin (2011) munkájában; a hazai szociológia képviselői közül pedig például Csurgó (2007), illetve Megyesi (2007) alkalmazták.

\section{Köszönetnyilvánítás}

A tanulmány alapját képező kutatás során a Nemzeti Tehetség Program pénzügyi támogatását is igénybe vettem. Emberi Erőforrások Minisztériuma Emberi Erőforrás Támogatáskezel” „Egyedi fejlesztést biztosító ösztöndíjak" NTP-EFÖ-P-15. 


\section{Irodalom}

Aitken, S., Valentine, G. (2006): Ways of knowing and ways of doing geographic research. In: Aitken, S., Valentine, G. (eds.): Approaches to human geography. Sage, London, Thousand Oaks, New Delhi, 1-12. http://doi.org/cnmb

Alsos, G. A., Carter, S. (2006): Multiple business ownership in the Norwegian farm sector: Resource transfer and performance consequences. Journal of Rural Studies, 3., 313-322. http://doi.org/fn9gqn

Anderson, B., Kearnes, M., McFarlane, C., Swanton, D. (2012): On assemblages and geography. Dialogues in Human Geography, 2., 171-189. http://doi.org/cnmc

Barlow, J. (1986): Landowners, property ownership and the rural locality. International Journal of Urban and Regional Research, 10., 309-329. http://doi.org/bd8rvk

Barnett, C. (2009): Cultural turn. In: Gregory, D., Johnston, R., Pratt, G., Watts, M. J., Whatmore, S. (eds.): The dictionary of human geography. Wiley-Blackwell, Chichester, 134-135.

Beedell, J., Rehman, T. (2000): Using social-psychology models to understand farmers' conservation behaviour. Journal of Rural Studies, 1., 117-127. http://doi.org/djpphm

Bibby, P., Brindley, (2013): Urban and rural area definitions for policy purposes in England and Wales: Methodology (V1.0). Office for National Statistics, London

Bingham, N. (2009): Assemblage. In: Gregory, D., Johnston, R., Pratt, G., Watts, M. J., Whatmore, S. (eds.): The dictionary of human geography. Wiley-Blackwell, Chichester, 38.

Boggs, J. S., Rantisi, N. M. (2003): The relational turn in economic geography. Journal of Economic Geography, 2., 109-116. http://doi.org/cv6p5x

Bowler, I. (1985): Some consequences of the industrialization of agriculture in the European community. In: Healey, M., Ilbery, B. W. (eds.): The industrialization of the countryside. Geo Books, Norwich, 75-98.

Clarke, D. B. (2006): Postmodern geographies and the ruins of modernity. In: Aitken, S., Valentine, G. (eds.): Approaches to human geography. Sage, London, Thousand Oaks, New Delhi, 107-121. http://doi.org/cm5c

Cloke, P. (1985): Whither rural studies. Journal of Rural Studies, 1., 1-10. http://doi.org/dg97fh

Cloke, P. (1997): Country backwater to virtual village? Rural studies and 'the cultural turn'. Journal of Rural Studies, 4., 367-375. http://doi.org/bv6bkh

Cloke, P., Thrift, N. (1987): Intra-class conflict in rural areas. Journal of Rural Studies, 1., 311-333. http://doi.org/cv54zj

Csurgó B. (2007): Képek és képzetek a mai magyar vidékről. In: Kovách I. (szerk.): Vidékiek és városiak: A tudás- és imázshasználat hatásai a vidéki Magyarországon. L'Harmattan, MTA PTI, Budapest, $45-66$.

Edwards, B. (1998): Charting the discourse of community action: perspectives from practice in rural Wales, Journal of Rural Studies, 1., 63-78. http://doi.org/dw47gt

Enticott, G. (2001): Calculating nature: the case of badgers, bovine tuberculosis and cattle. Journal of Rural Studies, 2., 149-164. http://doi.org/b9dd3g

G. Fekete, É., Lipták, K. (2011): Postmodern values in rural peripheries. Journal of Settlements and Spatial Planning, 1., 1-6.

Gregory, D., Johnston, R., Pratt, G., Watts, M. J., Whatmore, S. (eds.) (2009): The dictionary of human geography. Wiley-Blackwell, Chichester

Gyimesi Z. (2011): Thomas S. Kuhn gondolatainak szerepe a földrajztudomány történetének kontextualista elbeszélésében. Tér és Társadalom, 1., 81-99.

Hakli, J. (2009): Governmentality. In: Kitchin, R., Thrift, N. (eds.): International encyclopedia of human geography. Elsevier, Amsterdam, Oxford, 628-633. http://doi.org/fpm4r6

Halfacree, K. H. (1993): Locality and social representation: Space, discourse and alternative definitions of the rural. Journal of Rural Studies, 1., 23-37. http://doi.org/cqs34t

Harrison, P. (2006): Poststructuralist theories. In: Aitken, S., Valentine, G. (eds.): Approaches to human geography. Sage, London, Thousand Oaks, New Delhi, 122-135. http://doi.org/cm5h

Hess, M. (2009): Embeddedness. In: Kitchin, R., Thrift, N. (eds.): International encyclopedia of human geography. Elsevier, Amsterdam, Oxford, 423-428. http://doi.org/fbb8cj 
Holloway, L., Kneafsey, M. (2000): Reading the space of the farmer's market: a case study from the United Kingdom. Sociologia Ruralis, 3., 285-299. http://doi.org/d9rdh3

Jones, J. (2002): The cultural symbolisation of disordered and deviant behaviour: young people's experiences in a Welsh rural market town. Journal of Rural Studies, 2., 213-217. http://doi.org/bcx9nt

Jones, M. (2009): Phase space: geography, relational thinking, and beyond. Progress in Human Geography, 4., 487-506. http://doi.org/b5jps8

Kitchin, R. (2006): Positivistic geographies and spatial science. In: Aitken, S., Valentine, G. (eds.): Approaches to human geography. Sage, London, Thousand Oaks, New Delhi, 20-29. http://doi.org/cm5m

Kitchin, R., Thrift, N. (2009): International encyclopedia of human geography. Elsevier, Amsterdam, Oxford

Kovách I. (szerk.) (2012): Vidék az ezredfordulón. A jelenkori magyar vidéki társadalom szervezeti és hatalmi változásai. Argumentum, Budapest

Little, J. (1986): Feminist perspectives in rural geography: an introduction. Journal of Rural Studies, 1., 1-8. http://doi.org/b8r4gd

Little, J., Leyshon, M. (2003): Embodied rural geographies: developing research agendas. Progress in Human Geography, 3., 257-272. http://doi.org/bj42c2

Little, J., Panelli, R. (2003): Gender research in rural geography. Gender, Place \& Culture, 3., 281-289. http://doi.org/dbnx6r

MacKinnon, D. (2002): Rural governance and local involvement: assessing state-community relations in the Scottish Highlands. Journal of Rural Studies, 3., 307-324. http://doi.org/d45d5m

Marsden, T., Munton, R., Whatmore, S., Little, J. (1986): Towards a political economy of capitalist agriculture: a British perspective. International Journal of Urban and Regional Research, 4., 498-521. http://doi.org/fkzpwp

Mason, V., Hope, P. R. (2014): Echoes in the dark: Technological encounters with bats. Journal of Rural Studies, 33., 107-118. http://doi.org/f5s7jt

Matthews, H., Taylor, M., Sherwood, K., Tucker, F., Limb, M. (2000): Growing-up in the countryside: children and the rural idyll. Journal of Rural Studies, 2., 141-153. http://doi.org/ccbmjx

Megyesi B. (2007): A magyar lakosság vidékkel kapcsolatos attitűdjei. In: Kovách I. (szerk.): Vidékiek és városiak: A tudás- és imázshasználat hatásai a vidéki Magyarországon. L’Harmattan, MTA PTI, Budapest, 27-43.

Morris, C., Evans, N. (2004): Agricultural turns, geographical turns: retrospect and prospect. Journal of Rural Studies, 1., 95-111. http://doi.org/fmd5rp

Moyes, D., Ferri, P., Henderson, F., Whittam, G. (2015): The stairway to heaven? The effective use of social capital in new venture creation for a rural business. Journal of Rural Studies, 39., 11-21. http://doi.org/cnmd

Murdoch, J. (2000): Networks - a new paradigm of rural development? Journal of Rural Studies, 4., 407-419. http://doi.org/d2kz89

Murray, W. E. (2001): The second wave of globalisation and agrarian change in the Pacific Islands. Journal of Rural Studies, 2., 135-148. http://doi.org/dpbgzx

Owain, J. (2003): 'The restraint of beasts': rurality, animality, actor network theory and dwelling. In: Cloke, P. (eds.): Country visions. Pearson, London, 283-307.

Peet, R., Thrift, N. (1989): Political economy and human geography. In: Peet, R., Thrift, N. (eds.): New models in geography: The political economy perspective. Vol. 1. Unwin Hyman, London, 2-31. http://doi.org/dhpjnt

Phillips, M., Fish, R., Agg, J. (2001): Putting together ruralities: towards a symbolic analysis of rurality in the British mass media. Journal of Rural Studies, 1., 1-27. http://doi.org/dsgdtv

Phillipson, J., Bennett, K., Lowe, P., Raley, M. (2004): Adaptive responses and asset strategies: the experience of rural micro-firms and foot and mouth disease. Journal of Rural Studies, 2., 227-243. http://doi.org/dpdsm2

Robson, E. (2004): Children at work in rural northern Nigeria: patterns of age, space and gender. Journal of Rural Studies, 2., 193-210. http://doi.org/bxkbzd

Shepherd, J., Bibby, P. (2001): Developing a new classification of rural and urban areas for policy purposes - the methodology. Office for National Statistics, London

Thompson, N. (2005): Inter-institutional relations in the governance of England's national parks: A governmentality perspective. Journal of Rural Studies, 3., 323-334. http://doi.org/d4tk58 
Thrift, N. (1987): Manufacturing rural geography. Journal of Rural Studies, 3., 77-81. http://doi.org/d4ptvr Timár J. (2006): Nyugati hegemónia a földrajzban. In: Kiss A., Mezősi G., Sümeghy Z. (szerk.): Táj, környezet és társadalom: ünnepi tanulmányok Keveiné Bárány Ilona professzor asszony tiszteletére. SZTE Éghajlattani és Tájföldrajzi Tanszék; SZTE Természeti Földrajzi és Geoinformatikai Tanszék, Szeged, 707-716.

Timár J., Nagy E., Velkey G., Nagy G., Kugler J., Duray B., Barta Gy., Beluszky P. (2012): Társadalomtudósok a „periférián”. Tér és Társadalom, 3., 151-163.

Timár, J., Velkey, G. (2016): The relevance of the political economic approach: The interpretations of the rural in the migration decision of young women and men in an economically backward region. Journal of Rural Studies, 43., 311-322. http://doi.org/cnmf

Valentine, G. (2001): Whatever happened to the social? Reflections on the 'cultural turn' in British human geography. Norsk Geografisk Tidsskrift - Norwegian Journal of Geography, 3., 166-172. http://doi.org/dd5zhc

Walford, N. (2003): Productivism is allegedly dead, long live productivism. Evidence of continued productivist attitudes and decision-making in South-East England. Journal of Rural Studies, 4., 491-502. http://doi.org/dphszf

Walford, N. (2007): Geographical and geodemographic connections between different types of small area as the origins and destinations of migrants to Mid-Wales. Journal of Rural Studies, 3., 318-331. http://doi.org/cntfpv

Whatmore, S. (1991): Lifecycle or patriarchy? Gender divisions in family farming. Journal of Rural Studies, 1-2., 71-76. http://doi.org/c4578t

Winter, M. (2000): Strong policy or weak policy? The environmental impact of the 1992 reforms to the CAP arable regime in Great Britain. Journal of Rural Studies, 1., 47-59. http://doi.org/ct9cfx

Winter, M. (2003): Embeddedness, the new food economy and defensive localism. Journal of Rural Studies, 1., 23-32. http://doi.org/ff5g88

Woods, M. (1997): Discourses of power and rurality: local politics in Somerset in the 20th century. Political Geography, 6., 453-478. http://doi.org/bmj6jc

Woods, M. (1998): Researching rural conflicts: hunting, local politics and actor-networks. Journal of Rural Studies, 3., 321-340. http://doi.org/btc8wn

Woods, M. (2005): Rural geography: Processes, responses and experiences in rural restructuring. Sage, London, Thousand Oaks, New Delhi

Woods, M. (2009a): Rural geography. In: Kitchin, R., Thrift, N. (eds): International encyclopedia of human geography. Elsevier, Amsterdam, Oxford, 429-441. http://doi.org/cbcxtr

Woods, M. (2009b): Rural geography: blurring boundaries and making connections. Progress in Human Geography, 6., 849-858. http://doi.org/dzw9dv

Woods, M. (2010): Performing rurality and practising rural geography. Progress in Human Geography, 6., 835-846. http://doi.org/cr4hvq 